\title{
THE STUDY OF THE BIOLOGICAL ACTIVITY OF SOME COBALT(III) DIOXIMATES WITH FLUORINE CONTAINING ANIONS
}

\author{
Eduard Coropceanu*1, Alexandra Deseatnic ${ }^{2}$, Maria Stratan², Andrei Rija1 ${ }^{1}$, Olga Bologa ${ }^{1}$, Janna \\ Tiurin $^{2}$, Svetlana Labliuc ${ }^{2}$, Steliana Clapco ${ }^{2}$, Ion Bulhac ${ }^{1}$ \\ ${ }^{I}$ Institute of Chemistry, Academy of Sciences of Moldova, MD-2028 Chisinau, R. Moldova \\ ${ }^{2}$ Institute of Microbiology and Biotechnology, Academy of Sciences of Moldova, MD-2028 Chisinau, R. Moldova \\ E-mail :ecoropceanu@yahoo.com
}

\begin{abstract}
It was elaborated the methodology of synthesizing a series of new dioximates of Co(III) with the general formula $\left[\mathrm{Co}(\mathrm{DioxH})_{2}(\mathrm{~L})_{2}\right] \mathrm{X} \cdot \mathrm{nH}_{2} \mathrm{O}$, where DioxH - the dioxime anione: dimethylglyoxime $\left(\mathrm{DH}_{2}\right)$, 1,2-cyclohexanedionedioxime $\left(\mathrm{NioxH}_{2}\right) ; \mathrm{L}$ - thiocarbamide (Thio), pyridine (Py), aniline (An), sulphanilamide (Sam); $\mathrm{X}-\left[\mathrm{BF}_{4}\right],\left[\mathrm{ZrF}_{6}\right]^{2-},\left[\mathrm{TiF}_{6}\right]^{2-}$, whose structures have been studied with the help of contemporary physical methods: spectroscopy IR, UV-Vis, RMN ${ }^{1} \mathrm{H},{ }^{19} \mathrm{~F}, \mathrm{X}$-ray analysis. There were elaborated optimal conditions of using cobalt dioximates with fluorine in order to intensify the biosynthesis of amylases and lipases by Aspergillus and Rhizopus strains, respectively. The tested compounds increase the lipolytic activity of Rhizopus arrhisus micromycetes.
\end{abstract}

Keywords: $\mathrm{Co}(\mathrm{III})$ dioximates, anions with fluorine, models of biological objects, biostimulating properties, fungi, enzymes.

\section{Introduction}

The capacity of dioximates to get complex with transition metals draws the researchers' attention not just from the perspective of synthesizing $B_{12}$ vitamin models or haemoglobin [1-4], but also substances which manifest a wide spectrum of synthetic, analytic and structural possibilities [5-7]. The inclusion of fluorine ions or fluorine complex anions in cobalt dioximates favored the discovery of some ways of assembling complex molecules different from the case of using other halogens [8,9]. The positive action of cobalt (III) dioximates in the metabolic processes of microorganisms is well known. Modern biotechnology draws a special attention to the oriented synthesis of bioactive substances by microorganisms due to the important results obtained in the plan of fundamental studies with implications in medicine, microbiologic industry, chemistry, pharmaceutics, cosmetology etc. Due to some specific peculiarities like an increased reaction to environment changes, adaptive metabolism, short cycle of development, microorganisms are convenient for different researches. From another point of view, microorganisms are recognized as advantageous economic sources of obtaining a wide range of important bioactive substances.

A class of biologically active substances with a high importance in biology and multiple practical applications are the enzymes. Enzymatic preparations are widely used in different technological processes as well as in other fields of socio-human activities. Hydrolases - the enzymes which catalyze hydrolyze reactions, i.e. the reaction of splitting up compound substances of the type of polymers into simpler substances - have a major industrial importance, especially in medicine. The reactions of enzymatic hydrolysis are at the base of many modern technological processes. The growth of enzyme production can be obtained by improving the biosynthetical potential of microorganisms-sources. In this aspect, their use as biostimulators of the synthesizing process of coordinative compounds enzymes is of interest. Usually, these substances fulfill well determined functions of a vital importance for the organism: of transportation, accumulation, catalysts and biosynthesis stimulators of many biologic active substances. It is sufficient to mention that hemoglobin (central atom $-\mathrm{Fe}^{2+}$ ), chlorophyll (central atom $-\mathrm{Mg}^{2+}$ ) are metal complexes. The ions of many metals manifest an effect of activators of enzymatic systems [12]. The elements coordinately joined are less toxic and have a higher reagent capacity [13]. The physiological activity of metal complexes is mentioned in a series of works $[13,14,15]$ which point out their function as regulators and growth, development and productivity biostimulators of plants, as well as their important role in increasing animals specific immunity. The specialists in coordination chemistry explain the high activity of metal complexes through the molecule energetic and conformational state, conditioned by space geometry, the unusual system of link lengths, the coordination number etc. [16].

The use of coordination compounds is justified by two moments:

a) Considering their structure, metal complexes are close to natural biologic complexes which ensure the vital functions of the organism.

b) In most of the metal complexes, generators of complex are biometals - irreplaceable biologic catalysers, whose function is bound to proteins, specific ferments.

The analysis of different data proved that the biomass of Spirulina platensis, obtained through cultivation in the presence of cobalt coordinative compounds is characterized by a high content of ciancobalamine, protein, carotenoids and is balanced after other components [17]. Also, we found out that cobalt compounds with fluorine have stimulating 
properties upon some microorganisms [18]. The formation of compounds with cobalt reduces the toxic action of fluorine ions present in the nutritive medium. Structural and composition complexity, the presence of metals as central atoms attest the perspective of using coordinative compounds as stimulators and regulators of biologic processes in the microbial cell.

The stimulating action of coordination compounds upon the biosynthesis of enzymes can be exercised by the metal atom from the structure of complexes, in our case by the atom of Co(III). The importance of metals in enzymology is well known. The presence or the absence of metals in the medium can influence many characteristics of the microbial cell (at AND and ARN level, protein-enzymes synthesis etc.) $[19,20]$.

Using different proceedures, we synthesized a series of dioximates with fluorine or fluorinecontaining anions, whose composition, structure and physico-chemical properties were determined with the help of different modern methods [21-45] according to the scheme:

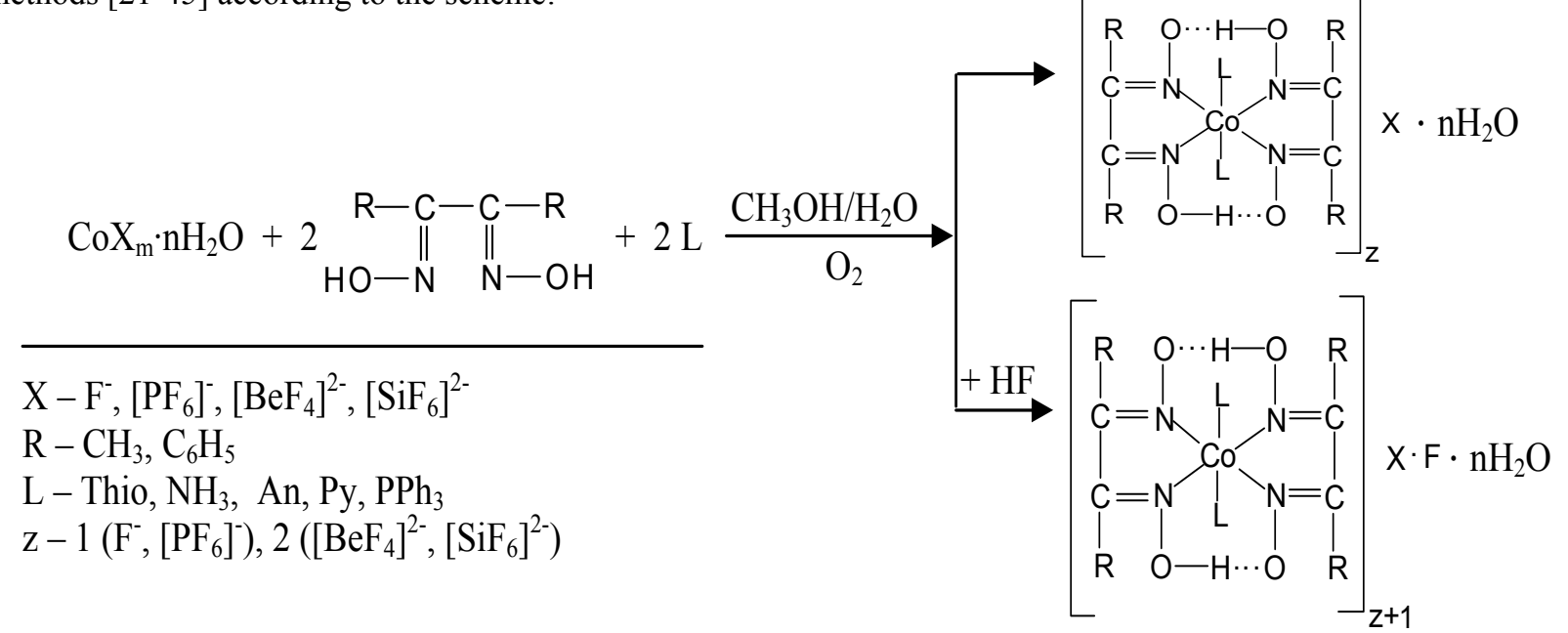

Considering the fact that cobalt(III) dioximates represent models of molecules with vital functions, their properties as biostimulators upon some fungi strains were tested. It was found that the introduction of cobalt(III) dioximates in a nutritive medium of Rhizopus and Aspergillus fungi stimulates biosynthetic processes (biomass accumulation, increase of enzymatic activity, reduction of the period of cultivation) and establishes enzymogenesis processes under conditions of stress [22,23,32-34,42-44].

\section{Results}

The method of synthesizing Co(III) dioximates which contain as axial ligands: thiocarbamide, aniline, sulphanilamide with the anions of $\left[\mathrm{BF}_{4}\right]^{-},\left[\mathrm{ZrF}_{6}\right]^{2-}$ and $\left[\mathrm{TiF}_{6}\right]^{2-}$ was elaborated. The composition of complexes was established and investigations with the help of the methods: spectroscopy in UV-Vis, IR and the crystalline structures of the complexes: $\left[\mathrm{Co}(\mathrm{DH})_{2}(\mathrm{Sam})_{2}\right]\left[\mathrm{BF}_{4}\right] \cdot \mathrm{H}_{2} \mathrm{O}, \quad\left[\mathrm{Co}(\mathrm{DH})_{2}(\mathrm{Py})_{2}\right]\left[\mathrm{BF}_{4}\right], \quad\left[\mathrm{Co}(\mathrm{DH})_{2}(\mathrm{Sam})_{2}\right]_{2}\left[\mathrm{ZrF}_{6}\right] \cdot 3 \mathrm{H}_{2} \mathrm{O}, \quad\left[\mathrm{Co}(\mathrm{DH})_{2}(\mathrm{Thio})_{2}\right]_{2}\left[\mathrm{ZrF}_{6}\right] \cdot \mathrm{H}_{2} \mathrm{O}$, $\left[\mathrm{Co}(\mathrm{DH})_{2}(\mathrm{An})_{2}\right]_{2}\left[\mathrm{ZrF}_{6}\right] \cdot 2 \mathrm{H}_{2} \mathrm{O},\left[\mathrm{Co}(\mathrm{NioxH})_{2}(\mathrm{An})_{2}\right]_{2}\left[\mathrm{ZrF}_{6}\right] \cdot 3 \mathrm{H}_{2} \mathrm{O},\left[\mathrm{Co}(\mathrm{NioxH})_{2}(\mathrm{Thio})_{2}\right]_{2}\left[\mathrm{TiF}_{6}\right] \cdot 3 \mathrm{H}_{2} \mathrm{O}$ etc. were determined by X-ray method. In the IR spectra of the complexes with dimethylglyoxime there are the bands of valence oscillations absorption and those of $\mathrm{Co}(\mathrm{DH})_{2}$ group deforming: $v_{\mathrm{as}}\left(\mathrm{CH}_{3}\right)=2930 \mathrm{~cm}^{-1}, v_{\mathrm{s}}\left(\mathrm{CH}_{3}\right)=2867 \mathrm{~cm}^{-1}, v_{\mathrm{as}}(\mathrm{C}=\mathrm{N})=1545 \mathrm{~cm}^{-1}$, $\delta_{\text {as }}\left(\mathrm{CH}_{3}\right)=1460 \mathrm{~cm}^{-1}, \delta_{\mathrm{s}}\left(\mathrm{CH}_{3}\right)=1374 \mathrm{~cm}^{-1}, v_{\text {as }}(\mathrm{N}=\mathrm{O})=1237 \mathrm{~cm}^{-1}, v_{\mathrm{s}}(\mathrm{C}=\mathrm{N})=1285 \mathrm{~cm}^{-1}, v_{\mathrm{s}}(\mathrm{N}=\mathrm{O})=1083 \mathrm{~cm}^{-1}, \gamma(\mathrm{OH})=973$ $\mathrm{cm}^{-1}, \delta(\mathrm{CNO})=730 \mathrm{~cm}^{-1}, v_{\text {as }}(\mathrm{Co}-\mathrm{N})=505 \mathrm{~cm}^{-1}$ and $v_{\mathrm{s}}(\mathrm{Co}-\mathrm{N})=430 \mathrm{~cm}^{-1}$. The complexes are a part of Co(III) transdioximates.

In $\left[\mathrm{Co}(\mathrm{DH})_{2}(\mathrm{Sam})_{2}\right]\left[\mathrm{BF}_{4}\right] \cdot \mathrm{H}_{2} \mathrm{O}$ and $\left[\mathrm{Co}(\mathrm{DH})_{2}(\mathrm{Sam})_{2}\right]_{2}\left[\mathrm{ZrF}_{6}\right] \cdot 3 \mathrm{H}_{2} \mathrm{O}$ two molecules of sulphanilamide are located in axial positions Lig-Co-Lig: $v_{\text {as }}\left(\mathrm{NH}_{2}\right)_{\text {free }}=3350 \mathrm{~cm}^{-1}, v_{\mathrm{s}}\left(\mathrm{NH}_{2}\right)_{\text {free }}=3250 \mathrm{~cm}^{-1}, v_{\mathrm{as}}\left(\mathrm{NH}_{2}\right)_{\text {coord }}=3280 \mathrm{~cm}^{-1}, v_{\mathrm{s}}\left(\mathrm{NH}_{2}\right)$ coord. $=3165 \mathrm{~cm}^{-1},\left[v_{\mathrm{as}}(\mathrm{CC})+\delta_{\mathrm{as}}(\mathrm{CCH})\right]=1595 \mathrm{~cm}^{-1},\left[v_{\mathrm{s}}(\mathrm{CC})+\delta_{\mathrm{s}}(\mathrm{CCH})\right]=1488 \mathrm{~cm}^{-1}, v_{\mathrm{as}}\left(\mathrm{SO}_{2}\right)=1312 \mathrm{~cm}^{-1}, v_{\mathrm{s}}\left(\mathrm{SO}_{2}\right)=1145 \mathrm{~cm}^{-1}$, $\gamma(\mathrm{CCC})=672 \mathrm{~cm}^{-1}$ and $562 \mathrm{~cm}^{-1}$. The $\mathrm{NH}_{2}$ amino-group is coordinated to the atom of cobalt. In the external sphere of the complexes there are the $\left[\mathrm{ZrF}_{6}\right]^{2-}$ or $\left[\mathrm{BF}_{4}\right]^{-}$, the molecules of crystallized water $\left(\mathrm{v}(\mathrm{OH}) \mathrm{H}_{2} \mathrm{O}=3400-3600 \mathrm{~cm}^{-1}\right)$. The band of $\left[\mathrm{ZrF}_{6}\right]^{2-}$ ion are registered in the region $v(\mathrm{Zr}-\mathrm{F})=472 \mathrm{~cm}^{-1}$, and those of the ion $\left[\mathrm{BF}_{4}\right]^{-2}: v_{\mathrm{as}}\left(\mathrm{BF}_{4}\right)=1085 \mathrm{~cm}^{-1}, v_{\mathrm{s}}\left(\mathrm{BF}_{4}\right)=760$ $\mathrm{cm}^{-1}, \delta(\mathrm{F}-\mathrm{B}-\mathrm{F})=525 \mathrm{~cm}^{-1}$. In the crystals $\left[\mathrm{Co}(\mathrm{DH})_{2}(\mathrm{Sam})_{2}\right]\left[\mathrm{BF}_{4}\right] \cdot \mathrm{H}_{2} \mathrm{O}$ and $\left[\mathrm{Co}(\mathrm{DH})_{2}(\mathrm{Sam})_{2}\right]_{2}\left[\mathrm{ZrF}_{6}\right] \cdot 3 \mathrm{H}_{2} \mathrm{O}$ are achieved complicated cyclic fragments both with and without the participation of complex anions (Fig. 1) are achieved.

In the spectra of the complexes containing thiocarbamide there take place shifts of absorption bands resembling with some exceptions: frequency values $v(\mathrm{NH}),\left[v(\mathrm{CS})+v(\mathrm{CN})+\delta\left(\mathrm{NH}_{2}\right)+\delta(\mathrm{HNC})\right]\left(\right.$ around $\left.1463 \mathrm{~cm}^{-1}\right)$; $[v(\mathrm{CN})+v(\mathrm{CS})+\delta(\mathrm{HNC})], \delta(\mathrm{NCN})$ and $\delta(\mathrm{NCS})$ reduce its values at thiocarbamide coordination, but the frequency values of $\delta\left(\mathrm{NH}_{2}\right)$ and $\left[\mathrm{v}(\mathrm{CS})+\mathrm{v}(\mathrm{CN})+\delta\left(\mathrm{NH}_{2}\right)+\delta(\mathrm{HNC})\right]$ (around $1415 \mathrm{~cm}^{-1}$ ) increase by $10-20 \mathrm{~cm}^{-1}$ [45]. In fresh solutions containing $\left[\mathrm{Co}(\mathrm{DH})_{2}(\text { Thio })_{2}\right]^{+}$, we can notice two absorption bands in regions 235 and $335 \mathrm{~nm}$, the first corresponding 
to $\mathrm{Co}(\mathrm{DH})_{2}$ grouping, which forms the cation equatorial plan, and the second - to those two thiocarbamide molecules located in a trans position [46].

In $\left[\mathrm{Co}(\mathrm{DH})_{2}(\mathrm{Thio})_{2}\right]_{2}\left[\mathrm{ZrF}_{6}\right] \cdot \mathrm{H}_{2} \mathrm{O}$, the coordination polyhedron of the atom of $\mathrm{Co}^{3+}$ represents an octahedron N4S2, formed of four nitrogen atoms of two dioxime anions and two sulphur atoms of thiocarbamide. Thiocarbamide molecules achieve movements under different angles towards the equatorial fragment: parallel, perpendicular and intermediary (Fig. 2).
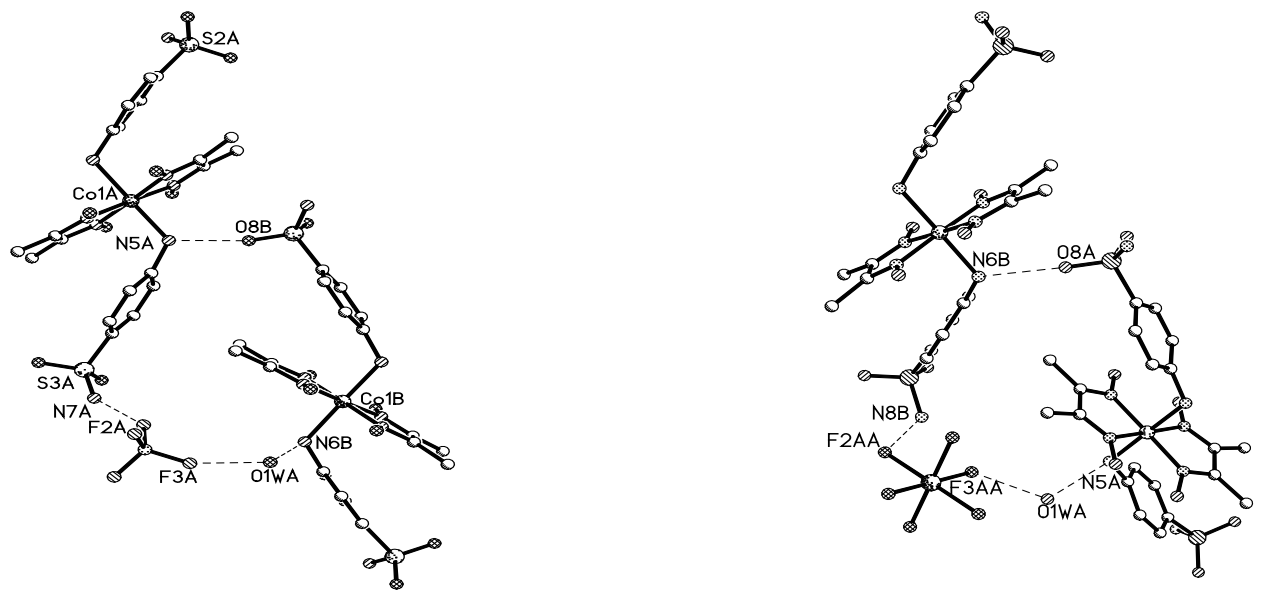

Fig.1. The process of forming cyclic fragments in $\left[\mathrm{Co}(\mathrm{DH})_{2}(\mathrm{Sam})_{2}\right]\left[\mathrm{BF}_{4}\right] \cdot \mathrm{H}_{2} \mathrm{O}$ and $\left[\mathrm{Co}(\mathrm{DH})_{2}(\mathrm{Sam})_{2}\right]_{2}\left[\mathrm{ZrF}_{6}\right] \cdot 3 \mathrm{H}_{2} \mathrm{O}$

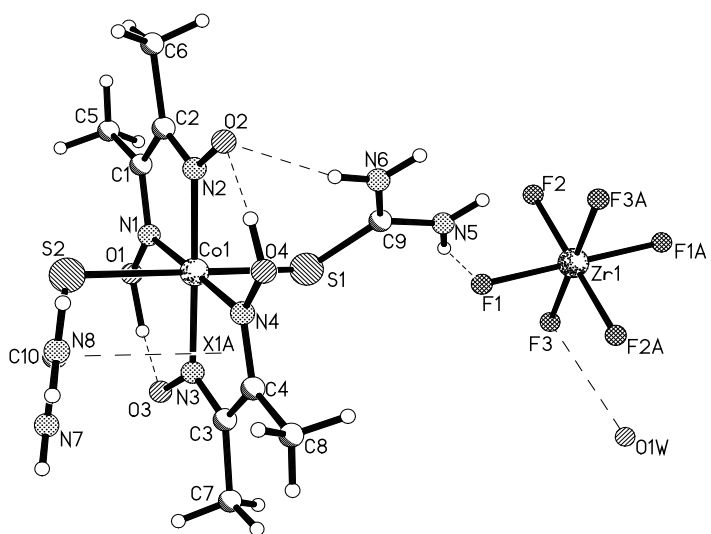

Fig. 2. The structure of $\left[\mathrm{Co}(\mathrm{DH})_{2}(\mathrm{Thio})_{2}\right]_{2}\left[\mathrm{ZrF}_{6}\right] \cdot \mathrm{H}_{2} \mathrm{O}$

In the complexes $\left[\mathrm{Co}(\mathrm{DH})_{2}(\mathrm{Thio})_{2}\right]_{2}\left[\mathrm{ZrF}_{6}\right] \cdot \mathrm{H}_{2} \mathrm{O}$ and $\left[\mathrm{Co}(\mathrm{NioxH})_{2}(\mathrm{Thio})_{2}\right]_{2}\left[\mathrm{ZrF}_{6}\right] \cdot 3 \mathrm{H}_{2} \mathrm{O}$, the coordination octahedron of the cobalt atom $4 \mathrm{~N} 2 \mathrm{~S}$ includes 4 nitrogen atoms of dioxime radicals and two sulphur atoms of thiocarbamide molecules. Dimethylglyoxime monodeprotoned anion are located practically in the same plane, between the oximic groups of the later being achieved the $\mathrm{O}-\mathrm{H} \cdots \mathrm{O}$ intermolecular hydrogen links. Also there take place $\pi-\pi$ and $\mathrm{N}-\mathrm{H} \cdots \mathrm{O}$ nonvalent intermolecular interactions. In the complex with 1,2-cyclohexanedionedioxime, two complex cations (A and B), crystalographically independent, are joined by means of $\mathrm{N}-\mathrm{H} \cdots \mathrm{F}$ hydrogen links which they form with $\left[\mathrm{ZrF}_{6}\right]^{2-}$ complex anion (Fig. 3).

In $\left[\mathrm{Co}(\mathrm{DH})_{2}(\mathrm{An})_{2}\right]_{2}\left[\mathrm{ZrF}_{6}\right] \cdot 2 \mathrm{H}_{2} \mathrm{O}$, two complex cations $\left[\mathrm{Co}(\mathrm{DH})_{2}(\mathrm{An})_{2}\right]^{+}$, centrosymmetrical and crystallographycally independent are united through a system of hydrogen links which occurs between the centrosymmetric anions $\left[\mathrm{ZrF}_{6}\right]^{2-}$ and the molecules of crystallized water. The coordination polyhedron of $\mathrm{Co}^{3+}$ atom presents a slightly denaturized octahedron N6 (Fig. 4).

In the compound of $\left[\mathrm{Co}(\mathrm{NioxH})_{2}(\mathrm{An})_{2}\right]_{2}\left[\mathrm{ZrF}_{6}\right] \cdot 3 \mathrm{H}_{2} \mathrm{O}$, the basic role belongs to the complex anion $\left[\mathrm{ZrF}_{6}\right]^{2-}$, which forms hydrogen links with the complex cation $\mathrm{N}-\mathrm{H} \cdots \mathrm{F}$ and $\mathrm{C}-\mathrm{H} \cdots \mathrm{F}$. The anions from the external sphere and the molecules of crystallizing water form a super molecular system on the base of some complicated nets of hydrogen links occurring between them (Fig. 5). 


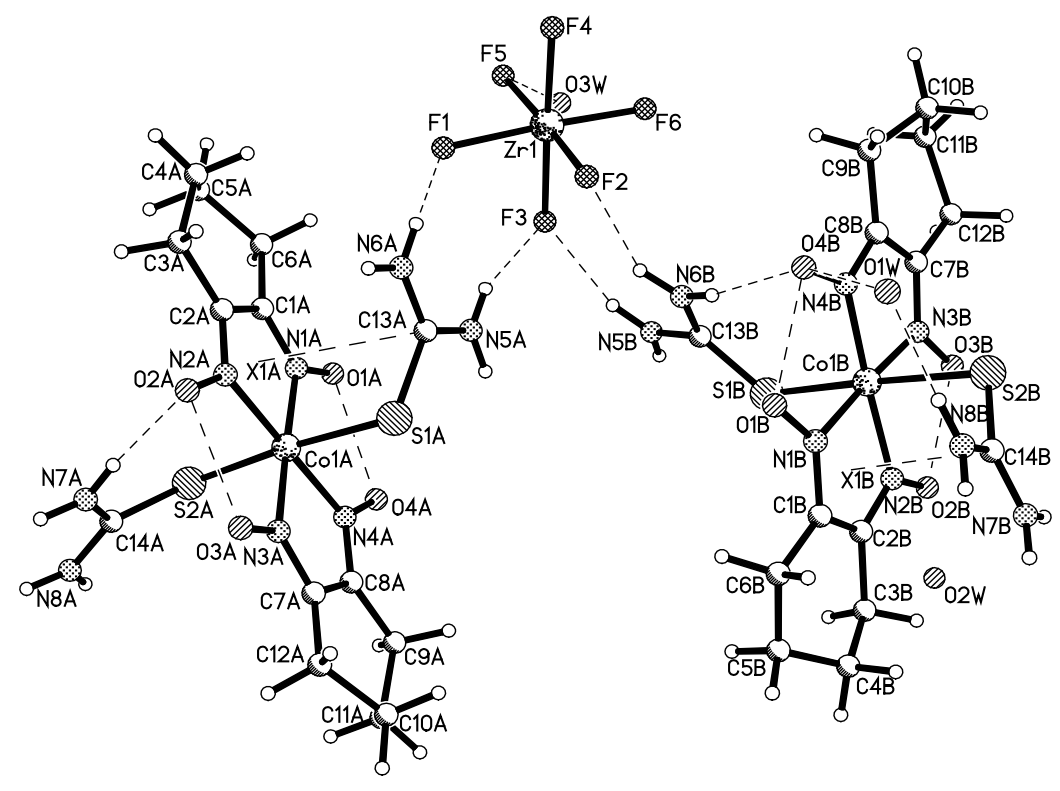

Fig. 3. Complex cation A

Complex cation B

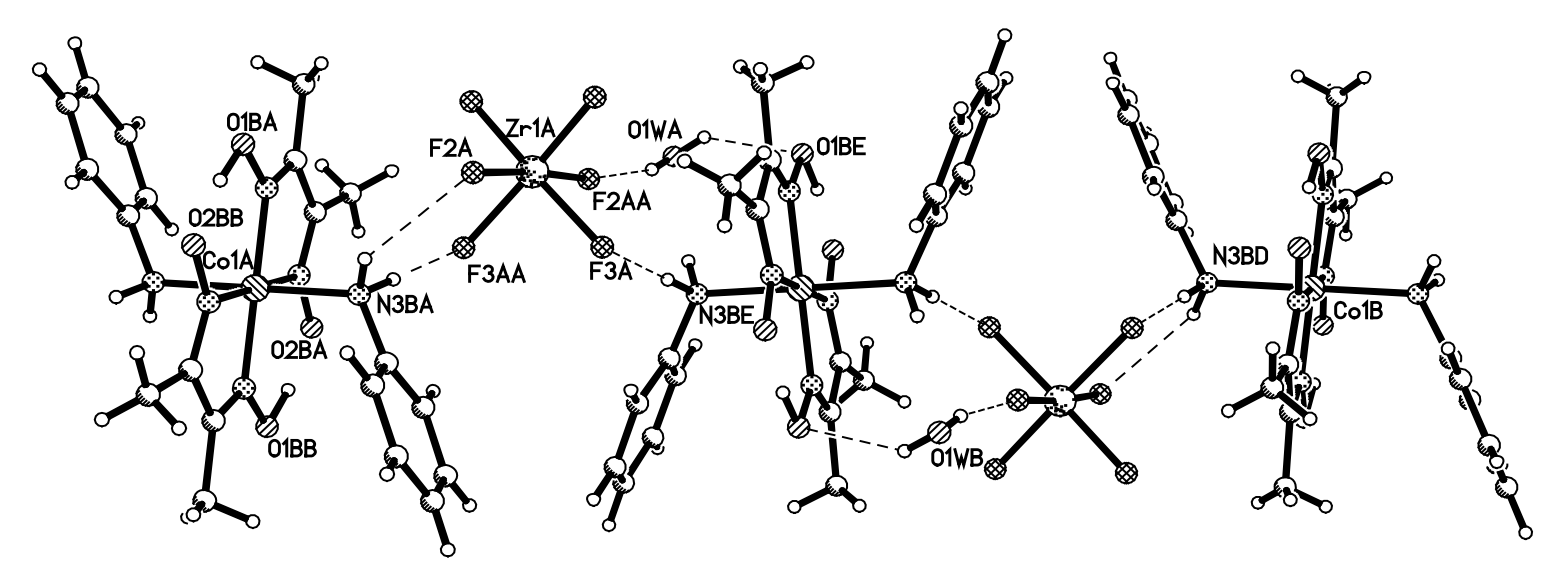

Fig. 4. The joining fragment of molecules $\mathrm{A}$ and $\mathrm{B}$ in the compound of $\left[\mathrm{Co}(\mathrm{DH})_{2}(\mathrm{An})_{2}\right]_{2}\left[\mathrm{ZrF}_{6}\right] \cdot 2 \mathrm{H}_{2} \mathrm{O}$

IR spectra analysis of dioximates with Py allows us to affirm that two pyridine molecules are coordinated through nitrogen to the cobalt atom, the main proofs being the rise of frequency values of most of the absorption bands: $v(\mathrm{CH})\left(3090-3125 \mathrm{~cm}^{-1}\right), \quad\left[v_{\text {as }}(\mathrm{CC})+\delta(\mathrm{CCH})\right]\left(1580-1610 \mathrm{~cm}^{-1}\right)$ and $\left[v_{\mathrm{s}}(\mathrm{CC})+\delta(\mathrm{CCH})\right]\left(1480-1500 \mathrm{~cm}^{-1}\right)[47] . \mathrm{In}$ $\left[\mathrm{Co}(\mathrm{DH})_{2}(\mathrm{Py})_{2}\right]\left[\mathrm{BF}_{4}\right]$, in an equatorial plane to the central atom there coordinate two dimethylgyoxime anions, joined through $\mathrm{O}-\mathrm{H} \cdots \mathrm{O}$ intramolecular hydrogen links, but in the positions 1.6 of the octahedron, there are nitrogen atoms of pyridine molecules. In the external sphere there are $\left[\mathrm{BF}_{4}\right]^{-}$anions (Fig. 6).

New dioximates of $\mathrm{Co}(\mathrm{III})$ with $\left[\mathrm{TiF}_{6}\right]^{2-}$ ions were obtained. In the IR spectra of synthesized compounds there are bands which indicate to their trans-configuration. The crystalline structure of $\left[\mathrm{Co}(\mathrm{NioxH})_{2}(\mathrm{Thio})_{2}\right]_{2}\left[\mathrm{TiF}_{6}\right] \cdot 3 \mathrm{H}_{2} \mathrm{O}(\mathrm{Fig}$. 7) was deciphered by means of X-rays.

The presence in the compound of a big number of $\mathrm{NH}_{2}$ donor-acceptor groups leads to the formation of a complicated system of intermolecular hydrogen links and to a special packing of crystal molecules which influence upon Thio molecules direction in relation with the equatorial plane. An important role in the process of forming crystalline structures is played by $\left[\mathrm{BF}_{4}\right]^{-},\left[\mathrm{ZrF}_{6}\right]^{2-}$ or $\left[\mathrm{TiF}_{6}\right]^{2-}$ complex anions. 


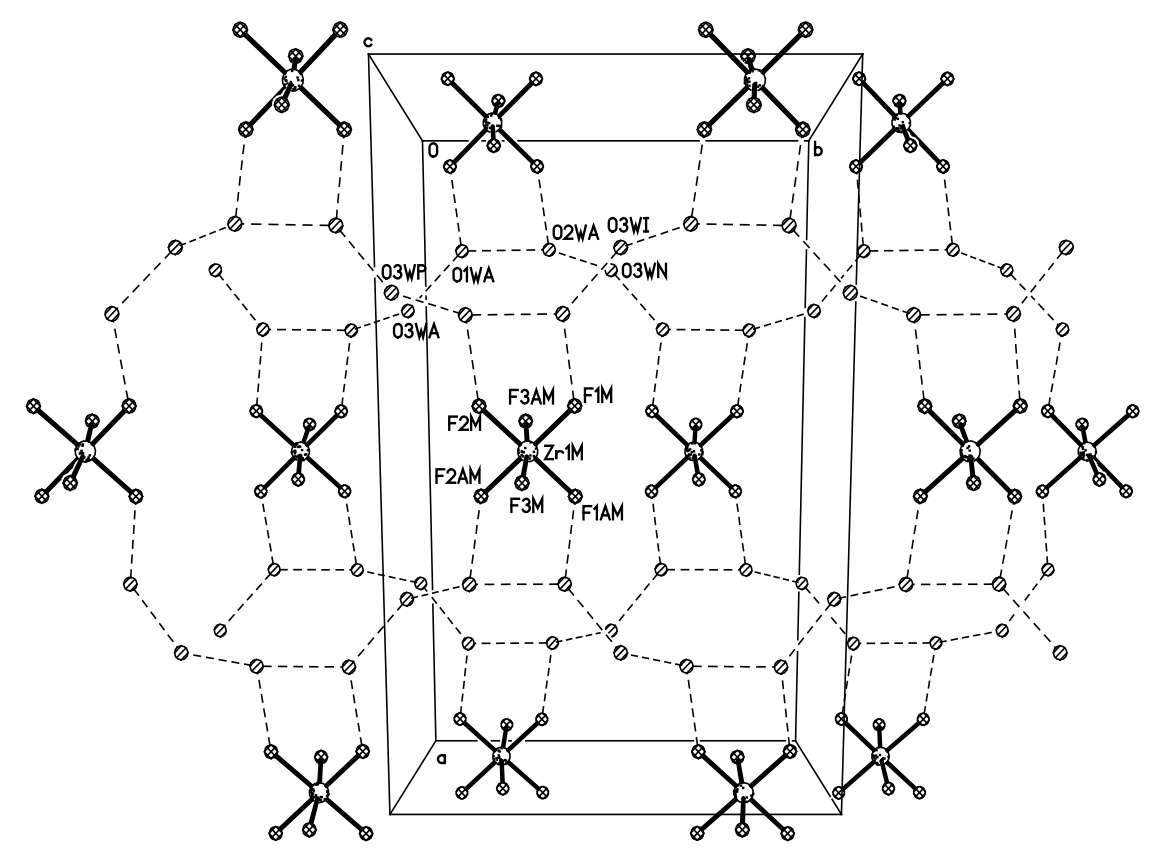

Fig. 5. The supramolecular system formed of $\left[\mathrm{ZrF}_{6}\right]^{2-}$ anions and water molecules

Obtaining of new cobalt(III) trans-dioximates widens the circle of compounds with a perspective of being used as catalyzers of biosynthetic processes. The common property of metal complexes, microelements and enzymes is the capacity of provoking in live cells new biological processes, used in small concentrations - 0,5-15 mg/L. An important role in manifesting the properties of metal complexes is played by the ligands from their component. The study of biological properties of a series of cobalt(III) complexes with different ligands and fluorinated anions in the external sphere marked their beneficient influence upon the enzymogenesis process of some fungal strains producing exocellular hydrolases with different enzymatic systems.

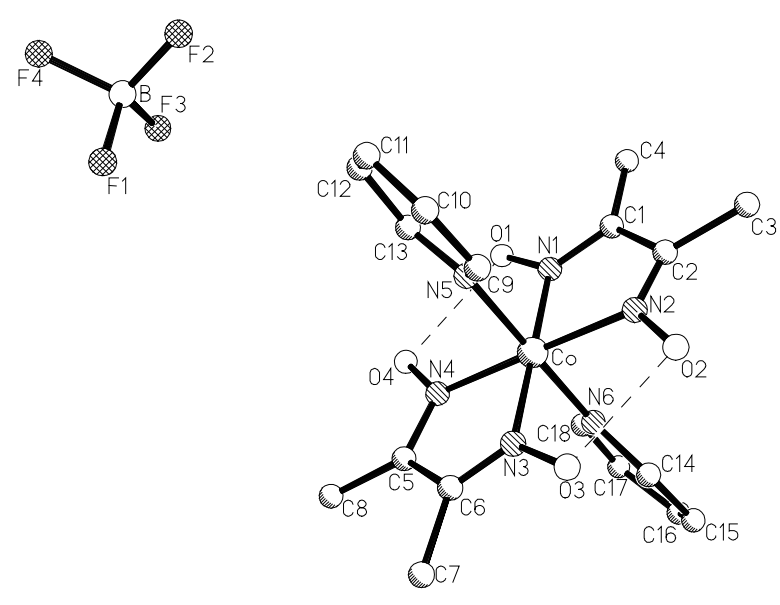

Fig. 6. The structure of $\left[\mathrm{Co}(\mathrm{DH})_{2}(\mathrm{Py})_{2}\right]\left[\mathrm{BF}_{4}\right]$ complex

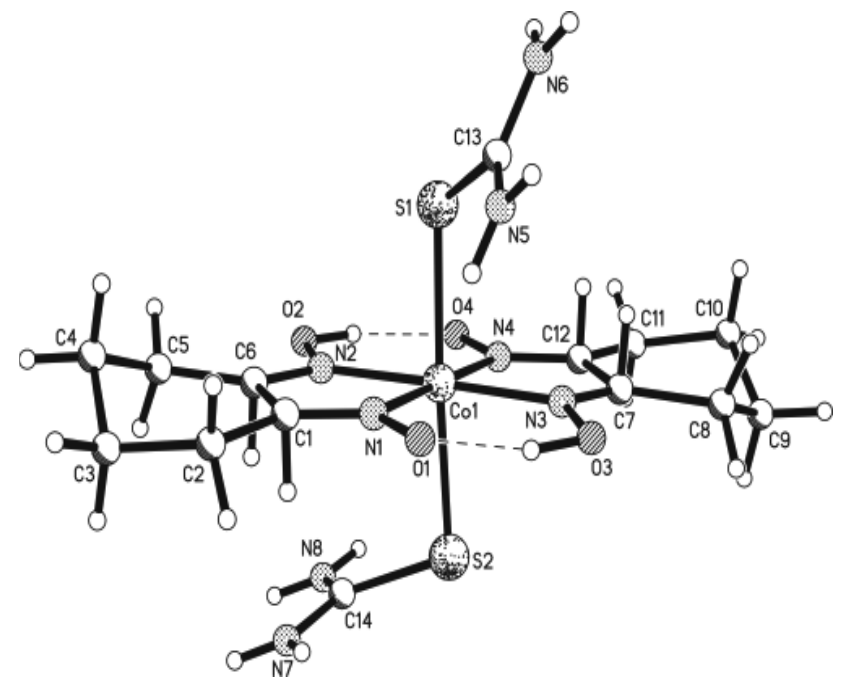

Fig. 7. The structure of $\left[\mathrm{Co}(\mathrm{NioxH})_{2}(\text { Thio })_{2}\right]^{+}$cation

Obtaining of new cobalt(III) trans-dioximates widens the circle of compounds with a perspective of being used as catalyzers of biosynthetic processes. The common property of metal complexes, microelements and enzymes is the capacity of provoking in live cells new biological processes, used in small concentrations - 0,5-15 mg/L. An important role in manifesting the properties of metal complexes is played by the ligands from their component. The study of biological properties of a series of cobalt(III) complexes with different ligands and fluorinated anions in the external sphere marked their beneficient influence upon the enzymogenesis process of some fungal strains producing exocellular hydrolases with different enzymatic systems. Thus, the introduction in the cultivation medium of Aspergillus niger CNMN FD 01 strain, producer of lipases, to the metal complex $\left[\mathrm{Co}(\mathrm{MH})_{2}(\mathrm{Py})_{2}\right]\left[\mathrm{BF}_{4}\right] \cdot \mathrm{H}_{2} \mathrm{O}$ increased the enzymatic activity by $30,0-$ 
$46,2 \%$. The coordinative compounds of cobalt(III) $\left[\mathrm{Co}(\mathrm{DH})_{2}(\mathrm{Thio})_{2}\right]_{3} \mathrm{~F}\left[\mathrm{SiF}_{6}\right] \cdot 1,5 \mathrm{H}_{2} \mathrm{O},\left[\mathrm{Co}(\mathrm{DH})_{2}\left(\mathrm{Thio}_{2}\right]_{2}\left[\mathrm{SiF}_{6}\right] \cdot 3 \mathrm{H}_{2} \mathrm{O}\right.$, $\left[\mathrm{Co}(\mathrm{DH})_{2}(\mathrm{Thio})_{2}\right]\left[\mathrm{BF}_{4}\right] \cdot 3 \mathrm{H}_{2} \mathrm{O}$ proved to be efficient stimulators for Rhizopus arrhizus $\mathrm{F} 67$ - producer of pectinases and Aspergillus niger 33 CNMN FD 06A - producer of amylases. The above mentioned compounds increased the enzymatic synthesis by $97,1-115,3 \%$ and $26.3-42,6 \%$, depending on the applied concentration and the strain origin [48]. The researches proved that the tested coordinative compounds modify not only the enzymatic activity but also the term of manifesting the maximum of enzymatic synthesis. It is important to establish the effect of coordination compounds depending on the composition of the internal and external sphere of metal complexes.

The present research had as object of study Aspergillus niger 33-19 CNMN FD 02A and Rhizopus arrhizus Fischer CNMN FD 03L strains. As inoculation was served the aqueous suspension of spores of 14 days culture, grown on oblique surfaces of agarized malt, at $28-30{ }^{\circ} \mathrm{C}$ in a quantity of $10 \%$ with the concentration of $10^{6} \mathrm{spores} / \mathrm{ml}$ was used as inoculation. In order to intensify the biosynthetical capacity of fungal strains there were used new dioxymates of cobalt(III) which contain in the internal sphere organic molecules (dimethylglyoxime, 1,2 cyclohexanedionedioxime, aniline), and in the external sphere fluorinated anions: $\left[\mathrm{ZrF}_{6}\right]^{2-},\left[\mathrm{TiF}_{6}\right]^{2-}:\left[\mathrm{Co}(\mathrm{NioxH})_{2}(\mathrm{An})_{2}\right]_{2}\left[\mathrm{ZrF}_{6}\right] \cdot 3 \mathrm{H}_{2} \mathrm{O}(\mathrm{I})$, $\left[\mathrm{Co}(\mathrm{DH})_{2}(\mathrm{An})_{2}\right]_{2}\left[\mathrm{ZrF}_{6}\right] \cdot \mathrm{H}_{2} \mathrm{O}(\mathrm{II}),\left[\mathrm{Co}(\mathrm{DH})_{2}(\mathrm{An})_{2}\right]_{2}\left[\mathrm{TiF}_{6}\right](\mathrm{III})$. The metal complexes were tested in three concentrations $-1,5$, and $10 \mathrm{mg} / \mathrm{L}$.

In the cultural liquids obtained in the experimental variants (with coordination compounds) and in the control variant (without coordination compounds) the enzymatic activity specific to the studied strains was essayed: the amylolytic activity was determined by means of the colorimetric method with iodine, using as a substrate $1 \%$ soluble starch solution in standard conditions of hydrolysis at $\mathrm{pH}-4,7$ for ordinary amylases and at $\mathrm{pH}-2,5$ for acid stable amylases. A unit of amylolytic activity is equivalent to the enzyme capacity in conditions determined by temperature, $\mathrm{pH}$ and the duration of cultivation of a gram of starch up to dextrins of a different molecular mass. The lipolytic activity was determined after the action upon olive emulsion oil in polyvinylic alcohol (Oto-Iamada method).

The analysis of data, obtained as a result of the study regarding the influence of cobalt(III) new dioximates upon the biosynthesis of ordinary (Tab. 1) and acid stable (Tab. 2) amylases by Aspergillus niger 33-19 CNMN FD 02A micromycete points out that the first two substances of $\left[\mathrm{Co}(\mathrm{NioxH})_{2}(\mathrm{An})_{2}\right]_{2}\left[\mathrm{ZrF}_{6}\right] \cdot 3 \mathrm{H}_{2} \mathrm{O}$ and $\left[\mathrm{Co}(\mathrm{DH})_{2}(\mathrm{An})_{2}\right]_{2}\left[\mathrm{ZrF}_{6}\right] \cdot 2 \mathrm{H}_{2} \mathrm{O}$, characterized by identical external sphere - the anion of $\left[\mathrm{ZrF}_{6}\right]^{2-}$ and differences in the composition of ligands $-\mathrm{DH}^{-}$and $\mathrm{NioxH}^{-}$, manifest a stimulating action during the initial stage of the synthesis of amylases (during the fourth and the fifth days of cultivation) at their application in small concentrations $-1-5 \mathrm{mg} / \mathrm{L}$. The stimulating effect was $20,0 \%$ and 15,0 $\%$ for ordinary amylases, and $22,1 \%$ and $23,0 \%$ for acid stable amylases.

Table 1

Modification of ordinary amylases activity (pH 4,7) of Aspergilllus niger 33-19 CNMN FD 02A micromycete under the influence of cobalt(III) complexes with fluorinated anions (u/ml)

\begin{tabular}{|c|c|c|c|c|c|c|c|c|c|}
\hline \multirow{3}{*}{ Coordination compounds } & \multirow{3}{*}{$\begin{array}{c}\text { Conc. } \\
\mathrm{CC}, \\
\mathrm{mg} / \mathrm{L}\end{array}$} & \multicolumn{8}{|c|}{ Activity } \\
\hline & & \multicolumn{2}{|c|}{ day 4} & \multicolumn{2}{|r|}{ day 5} & \multicolumn{2}{|r|}{ day 6} & \multicolumn{2}{|c|}{ day 7} \\
\hline & & $\mathrm{u} / \mathrm{ml}$ & $\begin{array}{c}\% \text { towards } \\
\text { control }\end{array}$ & $\mathrm{u} / \mathrm{ml}$ & $\begin{array}{c}\% \text { towards } \\
\text { control }\end{array}$ & $\mathrm{u} / \mathrm{ml}$ & $\begin{array}{c}\% \text { towards } \\
\text { control }\end{array}$ & $\mathrm{u} / \mathrm{ml}$ & $\begin{array}{c}\% \text { towards } \\
\text { control }\end{array}$ \\
\hline \multirow{3}{*}[\mathrm{Co}(\mathrm{NioxH})_{2}(\mathrm{An})_{2}]{$_{2}\left[\mathrm{ZrF}_{6}\right] \cdot 3 \mathrm{H}_{2} \mathrm{O}(\mathrm{I})$} & 1 & 159,3 & 117,0 & 183,5 & 106,0 & 142,6 & 80,1 & 175,9 & 104,9 \\
\hline & 5 & 163,4 & 120,0 & 173,1 & 100,0 & 132,5 & 74,5 & 167,5 & 100,0 \\
\hline & 10 & 122,7 & 90,0 & 173,1 & 100,0 & 132,5 & 74,5 & 167,5 & 100,0 \\
\hline \multirow{3}{*}[\mathrm{Co}(\mathrm{DH})_{2}(\mathrm{An})_{2}]{$_{2}\left[\mathrm{ZrF}_{6}\right] \cdot 2 \mathrm{H}_{2} \mathrm{O}(\mathrm{II})$} & 1 & 138,5 & 101,7 & 178,3 & 103,0 & 167,8 & 94,4 & 167,5 & 100,0 \\
\hline & 5 & 160,1 & 110,8 & 199,1 & 115,0 & 112,3 & 63,1 & 175,9 & 104,9 \\
\hline & 10 & 138,5 & 101,7 & 188,7 & 109,0 & 152,7 & 85,8 & 159,3 & 95,1 \\
\hline \multirow{3}{*}[\mathrm{Co}(\mathrm{DH})_{2}(\mathrm{An})_{2}]{$_{2}\left[\mathrm{TiF}_{6}\right](\mathrm{III})$} & 1 & 178,3 & 130,9 & 208,6 & 120,5 & 171,8 & 96,5 & 184,2 & 109,9 \\
\hline & 5 & 178,3 & 130,9 & 227,4 & 131,3 & 171,8 & 96,5 & 192,4 & 114,9 \\
\hline & 10 & 188,7 & 138,6 & 227,4 & 131,3 & 202,2 & 113,6 & 184,2 & 109,9 \\
\hline Control & - & 136,2 & 100 & 173,1 & 100 & 177,9 & 100 & 167,5 & 100,0 \\
\hline
\end{tabular}

The stimulating effect is more powerfully expressed at the complex containing the 1,2-cyclohexanedionedioxime anion. This fact is due to the capacity of some species of micromycetes to assimilate effectively and to include methoxylate cyclic substances [49] in the metabolic processes. 
Table 2

Modification of acid stable amylases activity (pH 2,5) of Aspergillus niger 33-19CNMN FD 02A micromycete under the influence of cobalt(III) complexes with fluorinated anions

\begin{tabular}{|c|c|c|c|c|c|c|c|c|c|}
\hline \multirow{3}{*}{ Coordination compounds } & \multirow{3}{*}{$\begin{array}{l}\text { Conc } \\
\mathrm{CC}, \\
\mathrm{mg} / \mathrm{L}\end{array}$} & \multicolumn{8}{|c|}{ Activity } \\
\hline & & \multicolumn{2}{|c|}{$\begin{array}{l}\text { day } 4 \\
\end{array}$} & \multicolumn{2}{|c|}{ day 5} & \multicolumn{2}{|r|}{ day 6} & \multicolumn{2}{|r|}{ day 7} \\
\hline & & $\mathrm{u} / \mathrm{ml}$ & $\begin{array}{c}\% \text { towards } \\
\text { control }\end{array}$ & $\mathrm{u} / \mathrm{ml}$ & $\begin{array}{c}\% \text { towards } \\
\text { control }\end{array}$ & $\mathrm{u} / \mathrm{ml}$ & $\begin{array}{c}\% \text { towards } \\
\text { control }\end{array}$ & $\mathrm{u} / \mathrm{ml}$ & $\begin{array}{c}\% \text { towards } \\
\text { control }\end{array}$ \\
\hline \multirow{3}{*}[\mathrm{Co}(\mathrm{NioxH})_{2}(\mathrm{An})_{2}]{$_{2}\left[\mathrm{ZrF}_{6}\right] \cdot 3 \mathrm{H}_{2} \mathrm{O}(\mathrm{I})$} & 1 & 262,1 & 122,1 & 335,1 & 128,0 & 227,3 & 76,3 & 251,0 & 108,8 \\
\hline & 5 & 255,8 & 118,8 & 307,5 & 117,5 & 227,3 & 76,3 & 240,6 & 104,3 \\
\hline & 10 & 196,1 & 91,1 & 227,6 & 86,9 & 229,9 & 93,9 & 219,8 & 95,3 \\
\hline \multirow{3}{*}[\mathrm{Co}(\mathrm{DH})_{2}(\mathrm{An})_{2}]{$_{2}\left[\mathrm{ZrF}_{6}\right] \cdot 2 \mathrm{H}_{2} \mathrm{O}(\mathrm{II})$} & 1 & 216,1 & 100,3 & 307,5 & 117,5 & 277,4 & 93,1 & 219,8 & 95,3 \\
\hline & 5 & 227,6 & 105,7 & 321,9 & 123,0 & 171,1 & 54,4 & 251,0 & 108,8 \\
\hline & 10 & 216,1 & 100,3 & 278,4 & 106,4 & 252,3 & 84,7 & 230,7 & 100,0 \\
\hline \multirow{3}{*}[\mathrm{Co}(\mathrm{DH})_{2}(\mathrm{An})_{2}]{$_{2}\left[\mathrm{TiF}_{6}\right](\mathrm{III})$} & 1 & 252,4 & 117,2 & 310,1 & 118,5 & 220,4 & 74,0 & 256,2 & 111,0 \\
\hline & 5 & 276,6 & 128,4 & 335,1 & 128,0 & 249,4 & 83,7 & 261,3 & 113,3 \\
\hline & 10 & 284,6 & 132,2 & 368,4 & 140,8 & 333,2 & 111,9 & 240,6 & 104,3 \\
\hline Control & - & 215,3 & 100 & 261,7 & 100 & 297,8 & 100 & 230,7 & 100,0 \\
\hline
\end{tabular}

To the end of the process of cultivation (the 5-th and the 6-th days), the difference between experiment and control in the variants I, II equilibrates. The data allow us to suppose that the tested compounds intensify microorganism development stages (lag-stage and exponential stage) characterized by processes of microorganisms adaptation and multiplication, a phenomenon which provoke a precocious biosynthesis of amylases confirmed by a considerable biosynthesis intensification of both ordinary and acid stable amylases (by 20,0 \% and, respectively, 22,1\%) during the fourth day towards the control variant. Microbiological researches confirm the supposition by stating micellar precocious abundance and the active sporulation in the experimental variants.

The activity of both types of amylases is strongly modified by the III-rd substance $\left[\mathrm{Co}(\mathrm{DH})_{2}\left(\mathrm{An}_{2}\right]_{2}\left[\mathrm{TiF}_{6}\right]\right.$ which contains the metal of titanium in the composition of the fluorinated anion, a fact which distinguishes it from the II-nd substance which contains zirconium in the fluorinated anion. The application of this complex accelerates the process of establishing the stationary stage of the strain biologic cycle - during the 4-th and the 5-th days in the experimental variant towards the 6-th day in the control variant, reducing the technologic cycle by 48 hours, a fact which presents economic advantages, besides, it considerably increases the enzymatic biosynthesis. The maximum of standard (ordinary) amylases activity in the experimental variants (metal complex concentration was 5 and $10 \mathrm{mg} / \mathrm{L}$ ) represents $227,4 \mathrm{u} / \mathrm{ml}$ in comparison with $177,9 \mathrm{u} / \mathrm{ml}$ in the control variant, and that of acid stable amylases consists of $368,4 \mathrm{u} / \mathrm{ml}$ in the experimental variant towards $297,8 \mathrm{u} / \mathrm{ml}$ in the control variant. The stimulating effect represents $38,6 \%$ and 32,2 $\%$ for standard and acid stable amylases, respectively. The activity of amylases in this variant remains superior to control during the whole process of cultivation, a fact which confirms that this complex stimulates not only microorganism development, but also provokes "de novo" biosynthesis of enzymes (Fig. 8).

Concerning the similar composition of the II-nd and III-rd compounds mentioned above in the text $\left[\mathrm{Co}(\mathrm{DH})_{2}(\mathrm{An})_{2}\right]_{2}\left[\mathrm{ZrF}_{6}\right],\left[\mathrm{Co}(\mathrm{DH})_{2}(\mathrm{An})_{2}\right]_{2}\left[\mathrm{TiF}_{6}\right]$, marked by the difference of complex anions $-\left[\mathrm{ZrF}_{6}\right]^{2-}$, $\left[\mathrm{TiF}_{6}\right]^{2-}$, we can conclude that the different action of this compound upon enzymatic synthesis and development processes of Aspergillus niger 33-19 CNMN FD 02A fungal strain is marked by the properties of $\left[\mathrm{TiF}_{6}\right]^{2-}$ complex anion.

The new access of increasing enzymatic activity in some experimental variants during the 7-th day of cultivation is provoked by microorganism secondary growth. At this stage we can follow under microscope the growth of young micelle new catenae.

As a result of researches there were selected optimal conditions for the application of cobalt(III) dioximates which contain fluorine in order to intensify the biosynthesis of ordinary and acid stable amylases by Aspergillus niger 33-19 CNMN FD 02A fungal strain, producer of exocellular amylases: when metal complexes - $\left[\mathrm{Co}(\mathrm{NioxH})_{2}\left(\mathrm{An}_{2}\right)_{2}\left[\mathrm{ZrF}_{6}\right] \cdot 3 \mathrm{H}_{2} \mathrm{O}\right.$, $\left[\mathrm{Co}(\mathrm{DH})_{2}(\mathrm{An})_{2}\right]_{2}\left[\mathrm{ZrF}_{6}\right] \cdot 2 \mathrm{H}_{2} \mathrm{O}$ are used as stimulators, the concentration was $1-5 \mathrm{mg} / \mathrm{L}$, the cultivation period was 5 days; for the compound $\left[\mathrm{Co}(\mathrm{DH})_{2}(\mathrm{An})_{2}\right]_{2}\left[\mathrm{TiF}_{6}\right]$ the concentration was $5-10 \mathrm{mg} / \mathrm{L}$, the cultivation period was 4-5 days, depending on the applied concentration. The process is accomplished in standard conditions of cultivation established for Aspergillus niger 33-19 CNMN FD 02A fungal strain in submerse culture [24]. 


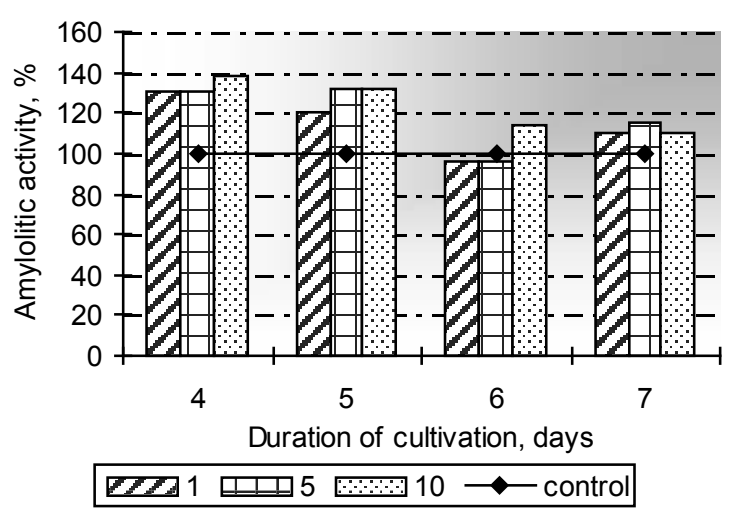

a)

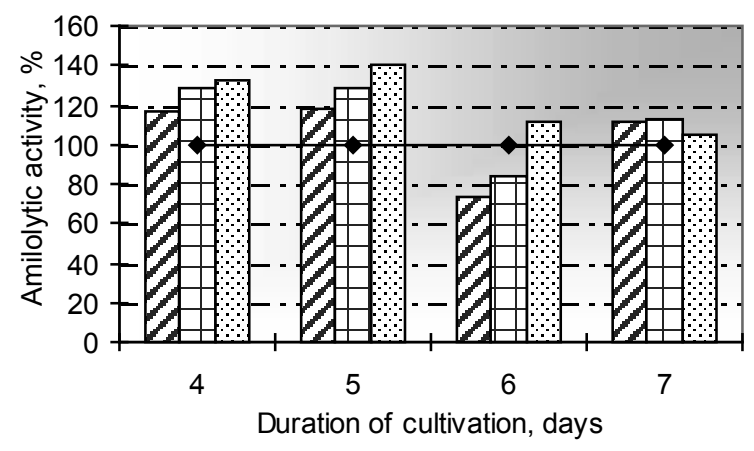

W71 एव5 $10 \multimap \bullet$ control

b)

Fig. 8. Modification of the activity of ordinary amylases ( $\mathrm{pH} 4$,7) synthesized by Aspergillus niger 33-19 CNMN FD 02A micromycete under the influence of $\left[\mathrm{Co}(\mathrm{DH})_{2}(\mathrm{An})_{2}\right]_{2}\left[\mathrm{TiF}_{6}\right]$

a. activity of ordinary amylases $(\mathrm{pH} 4,7)$

b. activity acid stabile amylases ( $\mathrm{pH} 2,5)$

The obtained data were applied in the process of elaborating a procedure of directed synthesis of amylases by Aspergillus niger 33-19 CNMN FD 02A fungal strain in submerse culture with the application of $\left[\mathrm{Co}(\mathrm{DH})_{2}(\mathrm{An})_{2}\right]_{2}\left[\mathrm{TiF}_{6}\right]$.

The procedure consists in: introducing the coordinative compound of $\left[\mathrm{Co}(\mathrm{DH})_{2}(\mathrm{An})_{2}\right]_{2}\left[\mathrm{TiF}_{6}\right]$, in a concentration of 5-10 mg/L, in the standard cultivation medium of Aspergillus niger 33-19 CNMN FD 02A in a submerse culture. The compound was added to the medium after the medium autoclaving, namely before the inoculation of the microorganism, aimed at avoiding the destruction of the complex structure. The culture was developed on $1 \mathrm{~L}$ Erlenmeyer flasks containing $200 \mathrm{ml}$ of nutrition medium, in conditions of continuing agitation $\left(200 \mathrm{rot} . / \mathrm{min} . .^{-1}\right)$, at $28-30{ }^{\circ} \mathrm{C}$, the duration of cultivation was 4-5 days. The composition of the nutrition medium $\left(\mathrm{g} \cdot \mathrm{L}^{-1}\right)$ : starch $-3,0$; been flour $-9,0$, wheat bran $-18,0 ;\left[\mathrm{Co}(\mathrm{DH})_{2}(\mathrm{An})_{2}\right]_{2}\left[\mathrm{TiF}_{6}\right]-0,01 ; \mathrm{MgSO}_{4}-0,5 ; \mathrm{KH}_{2} \mathrm{PO}_{4}-2,0 ; \mathrm{KCl}-0,5$; water $-1 \mathrm{~L} ; \mathrm{pH}-3,0$. The procedure ensures amylolytic activity with $23,7-28,9 \%$ towards the control, the technological cycle reduction with 24-48 hours.

Also studied was the influence of cobalt(III) dioximates with fluorine upon the process of Rhizopus arrhizus Fischer CNMN FD 03 L micromycete enzymogenesis which is an active producer of lipases. Lipases are the keyenzymes in the metabolism of lipids of all live organisms. The intensive study of lipolytic enzymes is conditioned not only by the theoretic interest towards them, but also by the possibility of using them in different technological processes. The data obtained after having determined the lipolytic activity in dynamics in the cultural liquid during the 1-st, 2-nd and the 3-rd days of cultivation are given in table 3 .

Concerning the I-st and the II-nd compounds, their stimulating effect manifests beginning with the first day of cultivation, the enzymatic activity being with $5,5-11,1 \%$ superior to control in the variants with mediums of 5-10 mg/L concentration. The maximum of biosynthesis for all the compounds is marked during the second day of cultivation, representing 122,2-166,6\% towards control and corresponds to the time of manifesting the maximum of biosynthesis in the control variant. Microscopical researches don't mark any indexes of culture development acceleration, a fact confirmed by biochemical results. This can be explained by the short cycle of Rhizopus arrhizus Fischer CNMN FD 03 L strain developments of 2 days, unlike Aspergillus niger 33-19 CNMN FD 02A strain whose cycle of development is of 6 days. The highest activity was obtained for the II-nd complexe, in the variants with the concentration of $5 \mathrm{mg} / \mathrm{L}$, representing respectively $93750 \mathrm{u} / \mathrm{ml}$ by comparison with $56250 \mathrm{u} / \mathrm{ml}$ in the control variant, fact which represents a rise of $66,6 \%$. The III-rd complex manifests a mechanism of action upon the process of strain enzymogenesis different from other complexes. The curve of the culture development cycle on the medium with such a complex repeats the curve on the witness medium, the difference consisting only in the maximum of lipases biosynthesis, more expressed during the second day of cultivation. Irrespective of the concentration in the applied diapason of this complex - 1, 5, or $10 \mathrm{mg} / \mathrm{L}$, the enzymatic activity represents $75000 \mathrm{u} / \mathrm{ml}$ towards $56250 \mathrm{u} / \mathrm{ml}$ in the control variant or by $33,3 \%$ superior to control. This differing behavior can be prescribed to the complex anion with titanium from the external sphere of the compound. 
Modification of Rhizopus arrhizus Fischer CNMN FD 03 L micromycete lipolytic activity under the influence of cobalt(III) with fluorinated anions

\begin{tabular}{|c|c|c|c|c|c|c|c|}
\hline \multirow[b]{3}{*}{ Coordination compounds } & \multirow{3}{*}{$\begin{array}{c}\text { Conc } \\
\mathrm{CC}, \\
\mathrm{mg} / \mathrm{L}\end{array}$} & \multicolumn{6}{|c|}{ Lipolytic activity, $\mathrm{u} / \mathrm{ml}$} \\
\hline & & \multicolumn{2}{|c|}{ day 1} & \multicolumn{2}{|c|}{ day 2} & \multicolumn{2}{|c|}{ day 3} \\
\hline & & $\mathrm{u} / \mathrm{ml}$ & $\begin{array}{c}\% \\
\text { towards } \\
\text { control }\end{array}$ & $\mathrm{u} / \mathrm{ml}$ & $\begin{array}{c}\% \text { towards } \\
\text { control }\end{array}$ & $\mathrm{u} / \mathrm{ml}$ & $\begin{array}{c}\% \text { towards } \\
\text { control }\end{array}$ \\
\hline \multirow{3}{*}[\mathrm{Co}(\mathrm{NioxH})_{2}(\mathrm{An})_{2}]{$_{2}\left[\mathrm{ZrF}_{6}\right] \cdot 3 \mathrm{H}_{2} \mathrm{O}(\mathrm{I})$} & 1 & 54625 & 105,5 & 68750 & 122,2 & 45000 & 100,0 \\
\hline & 5 & 54625 & 105,5 & 68750 & 122,2 & 45000 & 100,0 \\
\hline & 10 & 57500 & 111,1 & 68750 & 122,2 & 35000 & 77,8 \\
\hline \multirow{3}{*}[\mathrm{Co}(\mathrm{DH})_{2}(\mathrm{An})_{2}]{$_{2}\left[\mathrm{ZrF}_{6}\right] \cdot 2 \mathrm{H}_{2} \mathrm{O}(\mathrm{II})$} & 1 & 51750 & 100,0 & 75000 & 133,3 & 35000 & 77,8 \\
\hline & 5 & 57500 & 111,1 & 93750 & 166,6 & 45000 & 100,0 \\
\hline & 10 & 57500 & 111,1 & 81250 & 144,4 & 35000 & 77,8 \\
\hline \multirow{3}{*}[\mathrm{Co}(\mathrm{DH})_{2}(\mathrm{An})_{2}]{$_{2}\left[\mathrm{TiF}_{6}\right] \quad$ (III) } & 1 & 46000 & 88,9 & 75000 & 133,3 & 40000 & 88,9 \\
\hline & 5 & 51750 & 100,0 & 75000 & 133,3 & 45000 & 100,0 \\
\hline & 10 & 51750 & 100,0 & 75000 & 133,3 & 45000 & 100,0 \\
\hline Control & - & 51750 & 100 & 56250 & 100 & 45000 & 100,0 \\
\hline
\end{tabular}

\section{Conclusions}

- The method of synthesizing Co(III) dioximates, which contain thiocarbamide, pyridine, aniline, sulphanilamide with anions of $\left[\mathrm{BF}_{4}\right]^{-},\left[\mathrm{ZrF}_{6}\right]^{2-}$ and $\left[\mathrm{TiF}_{6}\right]^{2-}$ as axial ligands was elaborated.

- The composition of complexes was established and their crystalline structure by means of contemporary physical methods (IR, UV-Vis, DTGA).

As a result of the researches there were elaborated optimal conditions for using the dioximates of cobalt(III) with fluorine in order to intensify the biosynthesis of standard and acid stable amylases by Aspergillus niger 33-19 CNMN FD 02A strain and exocellular lipases by Rhizopus arrhizus Fischer CNMN FD 03 L strain:

The above-mentioned coordinative compounds are included in a sterile nutritive medium, after autoclaving in the form of a solution with well defined concentrations, directly before inoculation.

-The inclusion in the cultivation medium (in a concentration of $1-5 \mathrm{mg} / \mathrm{L}$ ) of $\left[\mathrm{Co}(\mathrm{NioxH})_{2}\left(\mathrm{An}_{2}\right]_{2}\left[\mathrm{ZrF}_{6}\right] \cdot 3 \mathrm{H}_{2} \mathrm{O}(\mathrm{I})\right.$, $\left[\mathrm{Co}(\mathrm{DH})_{2}(\mathrm{An})_{2}\right]_{2}\left[\mathrm{ZrF}_{6}\right] \cdot \mathrm{H}_{2} \mathrm{O}(\mathrm{II})$ modified the duration of Aspergillus niger 33-19 CNMN FD 02A strain cultivation, reducing the technologic cycle by 24 hours.

- The introduction of Aspergillus niger 33-19 CNMN FD 02A strain in the cultivation medium (in a concentration of $5-10 \mathrm{mg} / \mathrm{L})$ of $\left[\mathrm{Co}(\mathrm{DH})_{2}(\mathrm{An})_{2}\right]_{2}\left[\mathrm{TiF}_{6}\right]$ (III) coordinative compounds, which contain the complex anion with titanium and fluorine, reduce the technologic cycle by 48 hours, ensuring the rise of standard amylases activity by $27,8 \%$ and acid stable amylases by $23,7 \%$. The enzymatic activity in this variant remains superior to control during the whole period of cultivation.

- The tested dioximates of cobalt(III) with fluorine don't modify the duration of Rhizopus arrhizus Fischer CNMN FD $03 \mathrm{~L}$ micromycete - producer of exocellular lipases.

- At the introduction of $\left[\mathrm{Co}(\mathrm{NioxH})_{2}(\mathrm{An})_{2}\right]_{2}\left[\mathrm{ZrF}_{6}\right] \cdot 3 \mathrm{H}_{2} \mathrm{O}(\mathrm{I})$ and $\left[\mathrm{Co}(\mathrm{DH})_{2}(\mathrm{An})_{2}\right]_{2}\left[\mathrm{TiF}_{6}\right]$ (III) compounds in the cultivation medium of Rhizopus arrhizus Fischer CNMN FD 03 L micromycete, the lipolytic activity superior to control, registered in the variants with the concentration of $1 \mathrm{mg} / \mathrm{L}$ for complexe (I) representing $68750 \mathrm{u} / \mathrm{ml}$ by comparison with 56250 $\mathrm{u} / \mathrm{ml}$ on the control medium, which represents a rise of $22,25 \%$. The highest lipolytic activity was registered in the variants with coordinative compounds of $\left[\mathrm{Co}(\mathrm{DH})_{2}(\mathrm{An})_{2}\right]_{2}\left[\mathrm{ZrF}_{6}\right] \cdot 2 \mathrm{H}_{2} \mathrm{O}$ (II) at the application of the concentration of 5 $\mathrm{mg} / \mathrm{L}-93750 \mathrm{u} / \mathrm{ml}$ towards $56250 \mathrm{u} / \mathrm{ml}$ on the control medium, the increasing constituting $66,6 \%$.

- The external sphere influence of cobalt(III) coordination compounds with fluorine experimented upon the processes of enzymatic development and synthesis at micellar fungi-producers of exocellular hydrolysis was marked.

Acknowledgements

This work was supported by the grant 08.819.05.06A (CSŞDT) 


\section{References}

[1]. Schrauzer G.N., Windgassen R.J. J.Am.Chem.Soc., 1967, V. 89, p. 1999-2007.

[2]. Basam M.A., Hamza M.S.A., Felluga A., et al. Eur. J. Inorg. Chem., 2003, p. 3738-3743.

[3]. Fonda E., Michalowicz A., Randaccio L. et al. Eur. J. Inorg. Chem., 2001, p. 1269-1278.

[4]. Bowman K., Gaughan A.P., Dori Z. J. Amer. Chem. Soc., 1972, V.94, N3, p. 727-731.

[5]. Toscano P.J., Marzilli L.G. Prog. Inorg. Chem., 1984, V. 31, p. 105-109.

[6]. McCauley K.M., Wilson S.R., Van der Donk W.A Inorg. Chem., 2002, V. 41, p. 393-404.

[7]. Bresciani-Pahor N., Farcolin M., Marzilli L.G. et al. Coord. Chem. Rev., 1985, V.63, № 4, p. 1-125.

[8]. Simonov Yu.A., Dvorkin A.A., Gulea A.P. et al. Dokl. Akad. Nauk SSSR, 1989, V.305, №3, p. 635-638.

[9]. Simonov Yu.A., Bologa O.A., Gulea A.P. et al. Koord. Khim., 1994, V.20, №2, p. 106-110.

[10]. Gulea A.P., Rudic V.F., Gerbeleu N.V. et al. Patent 1616111 (USSR).

[11]. Deseatnic A.A., Tiurina J.P., Vinogradov S.P. et al. Effective Technologies for Producing New Enzyme Preparates of Microbic Origin and their Utilization in Processing Branches. Chişinău, 1998.

[12]. Dediuhin E.G., Eroshin V.K. Uspehi microbiologii, 1992, 25, c. 126-142.

[13]. Parpiev N.A., Kushakbal A., Azimov M.M. Coordination Compounds of Metals with Medicinal Preparates. Tashkent: FAN, 1982.

[14]. Kriss E.E., Volchenscova I.I., Grigorieva A.S. Coordination Compounds in Medicine. Kiev: Naukova Dumka, 1986.

[15]. Toma S.I., Veliksar S.T., Shandru I.A., Turta C.I., Vorontsov V.A. Moldova's Horticulture and Viticulture, 1987, №9, c. 41-43.

[16]. Palamaru M.N., Iordan A.N., Cecal A. Bioinorganic Cemisty and Life Metals. Iaşi: BIT, 1997.

[17]. Rudic V., Codreanu S., Gulea A., Novițchi G. Bul. AŞM, Series „Biological and Chemical Sciences”, 1995, 4, p. 23-26.

[18]. Rudic V. New Aspects of Modern Biotechnology. Chişinău: Ştiinţa, 1993.

[19]. Kvesitadze G.I. Fungous and Bacterial Amylases. Tbilisi: Metsnisreba, 1984.

[20]. Konovalov S.A. Biosynthesis of Enzymes by Micro-organisms. Moskow: Pischprom, 1982.

[21]. Simonov Yu.A., Kravtsov V.Kh., Gerbeleu N.V., Bologa O.A., Coropceanu E.B. Zh. Neorg. Khim, 1999, T.44, №9, p. 1468-1476.

[22]. Gerbeleu N., Coropceanu E., Deseatnic A., Simonov Yu., Bologa O., Tiurin J., Labliuc S., Kravtsov V. Annals of “AL.I. CUZA" University, Iaşi, 1999, V.7, Nr.2, p. 281-284.

[23]. [Coropceanu E., Deseatnic A., Gerbeleu N., Tiurin J., Labliuc S., Bologa O. Annals of MSU, Series "Chemical and Biological Sciences", 2000, p. 256-258.

[24]. Coropceanu E., Gărbălău N., Bologa O., Cernei G. Annals of MSU, Series "Chemical and Biological Sciences”, 2000, p. 312-314.

[25]. Gulea A., Coropceanu E., Bologa O., Gerbeleu N. Annals of MSU, Series "Chemical and Biological Sciences”, 2001, p. 250-252.

[26]. Simonov Yu.A., Gerbeleu N.V., Gdaniec M., Bourosh P.N., Coropceanu E.B., Bologa O.A. Koord. Khim., 2001, V.27, №5, p. 368-379.

[27]. Coropceanu E. Annals of MSU, Series "Chemical and Biological Sciences”, 2001, p. 247-249.

[28]. Malinovskii S.T., Coropceanu E.B., Zavodnik V.E., Bologa O.A. Kristallografiya, 2002, V.47, №1, p.. 58-61.

[29]. Malinovskii S.T., Coropceanu E.B., Bologa O.A., Belskii V.K. Koord. Khim., 2002, V.28, № 5, p. $370-376$.

[30]. Bourosh P.N., Coropceanu E.B., Simonov Yu.A., Gdaniec M., Bologa O.A., Gerbeleu N.V. Koord. Khim., 2002, V.28, № 9, p. 689-697.

[31]. Bourosh P.N., Coropceanu E.B., Simonov Yu.A., Gdaniec M., Bologa O.A., Gerbeleu N.V. Zh. Neorg. Khim., 2002, V.47, №10, p. 1604-1609.

[32]. Deseatnic A.A., Gerbeleu N.V., Coropceanu E.B., Tiurina J.P., Labliuc S.V., Bologa O.A., Clapco S.I. Koord. Khim., 2002, V.28, №2, p. 144-145.

[33]. Coropceanu E., Bologa O., Deseatnic A., Tiurin J., Sirbu T., Gerbeleu N. Bul. of Polyt. Inst. Iaşi, T. XLIX (LIII), Fasc. 5, 2003, p. 293-298.

[34]. Deseatnic A., Sirbu T., Coropceanu E., Tiurin J., Gerbeleu N., Bologa O., Labliuc S. Bul. of AŞM, Series „Biological and Chemical Sciences”, 2003, Nr. 2, p. 112-117.

[35]. Malinovskii S.T., Bologa O.A., Coropceanu E.B., Luboradzki R., Gerbeleu N.V. Koord. Khim., 2004, V. 30, № 5, p. 363-369.

[36]. Bourosh P.N., Coropceanu E.B., Bologa O.A., Gdaniec M., Simonov Yu.A., Gerbeleu N.V. Koord. Khim., 2004, V. 30, № 6, p. 403-409.

[37]. Malinovskii S.T., Bologa O.A.., Coropceanu E.B., Gerbeleu N.V. Kristallografiya, 2004, V. 49, №5, p. 895-898.

[38]. Bourosh P.N., Gerbeleu N.V., Gdaniec M., Simonov Yu.A., Bologa O.A., Coropceanu E.B. Zh. Neorg. Khim., 2006, V.51, №2, p. 309-315. 
[39]. Gerbeleu N.V., Simonov Yu.A., Bologa O.A., Bourosh P.N., Coropceanu E.B. Zh. Neorg. Khim., 2006, V.51, №5, p. 785-787.

[40]. Coropceanu E.B., Rija A.P, Bologa O.A., Malinovskii S.T., Gdaniec M. Zh. Struct. Khim., 2007, V.48, №5, p. 532-538.

[41]. Coropceanu E.B., Rija A.P, Shofranskii V.N., Bologa O.A., Gdaniec M., Malinovskii S.T. Zh. Struct. Khim., 2007, V. 48, №6, p. 1175-1182.

[42]. Gerbeleu N., Simonov Yu., Deseatnic A., Bologa O., Kravtsov V., Coropceanu E., Tiurin J., Labliuc S. Patent MD 1203. 1999.

[43]. Deseatnic A., Tiurin J., Gerbeleu N., Coropceanu E., Labliuc S., Bologa O. Patent MD 1748. 2002.

[44]. Gerbeleu N., Simonov Yu., Bourosh P., Deseatnic A., Coropceanu E., Bologa O., Condruc V., Clapco S. Patent MD 2833. 2005.

[45]. Haritonov Yu.Ya., Brega V.D., Ablov A.V. Zh. Neorg. Khim., 1970, V.15, №11, p. 3163-3164.

[46]. Ablov A.V., Bovykin B.A. Zh. Neorg. Khim., 1965, V.10, №1, p. 53-60.

[47]. Sverdlov L.M., Konver M.A., Krainov E.P. Oscilation Spectra of Multiatom Molecules. Moskow: Nauka. 1970.

[48]. Gracheva I.M., Grachev Yu.P., Mosichev M.S. Laboratory Practicum for Enzymes Preparates Technology. Moskow: Light and Food Industry, 1992, p. 57-70, 75-76.

[49]. Bilai V.I. Methods of Experimental Mycology. Kiev: Naukova Dumka, 1973. 